\title{
Anti-proliferative, Anti-angiogenic and Anti-inflammatory Effects of Moringa peregrina Leaf Extracts on Testosterone- Induced Benign Prostatic Hyperplasia in Rats
}

\author{
Mazhar Salim Al Zoubi', Wesam Al Khateeb², Musab El-Oqlah², Mu'ath \\ Migdady $^{2}$, Manl Issam Abu Al-Arja', Muna Bzour ${ }^{2}$, Ahmad El-Oqlah ${ }^{3}$, Samah \\ Almubarak ${ }^{2}$, Mahmoud A Al-Qudah ${ }^{4}$, Khalid Al-Batayneh², Michella Mkhael ${ }^{5}$, \\ Ahmed Elokda ${ }^{6}$, Prawej Ansari ${ }^{7}$, JMA Hannan ${ }^{7}$, Mohamed M Nasef ${ }^{8}$, Murtaza \\ M Tambuwala ${ }^{5}$, Hamid A Bakshi ${ }^{5 *}$
}

\begin{abstract}
Aim: To investigate the potential anti-inflammatory and biochemical effects of Moringa peregrina leaf extracts on testosterone-induced benign prostatic hyperplasia (BPH) in rats. Methods: Six groups of rats (each group included 5 rats) were included in this study. The groups included: 1) the control group, 2) the testosterone-induced BPH group, 3) with $50 \mathrm{mg} / \mathrm{kg}$ bwt (bodyweight) oil-treated BPH, 4) with $100 \mathrm{mg} / \mathrm{kg}$ bwt. oil-treated BPH, 5) with 500mg/kg bwt. ethanol treated BPH and 6) with 1,000 mg/kg bwt. aqueous treated BPH group. Biochemical markers were measured to evaluate the effect of $M$. peregrina leaf extracts. Results: Our results showed a significant improvement in the thickness of epithelial cells of the BPH glandular tissues when treated with different $M$. peregrina extracts $(\mathrm{p}<0.05)$. In addition, $M$. peregrina extracts showed anti-inflammatory, anti-proliferative and anti-angiogenesis effects on the BPH tissues by reduction of IL-6, PCNA and VEGF-A, respectively. Conclusion: Our preclinical study concluded that M. peregrina leaf extracts showed a significant effect on $\mathrm{BPH}$ by reducing inflammation, proliferation, and angiogenic processes with no signs of toxicity.
\end{abstract}

Keywords: Benign prostatic hyperplasia- anti-inflammation- anti-proliferation- anti-angiogenesis- M. peregrina

Asian Pac J Cancer Prev, 23 (1), 161-169

\section{Introduction}

Benign prostatic hyperplasia $(\mathrm{BPH})$ is a non-cancerous enlargement of the prostate gland that can affect greater than $25 \%$ of males over 50 years old and the majority of males in their 80s (McVary, 2006). Once diagnosed, $\mathrm{BPH}$ has a negative health impact on the quality of life. Most of the current active clinical treatments in $\mathrm{BPH}$ involve procedural interventions accompanied by conventional treatments of beta-blockers and 5-alpha reductase inhibitors (5-ARIs) depending on the size of the prostate. Likewise, another treatment option includes the use of phosphodiesterase-5 (PDE-5) inhibitors (Clifford and Farmer 2000; Van Asseldonk et al., 2015). However, the current BPH treatments have been reported to be associated with side effects including loss of libido, erectile dysfunction, and ejaculatory disorders (Mirone et al., 2011). Therefore, continuous investigation of novel drug therapies is in progress (Buford et al., 2019). Indeed interest in complementary and alternative medicine (CAM) treatment options for BPH have become more prevalent in recent years in Europe and the USA (Fourcade et al., 2008; Smith et al., 2015). A list of different phytotherapy drugs to treat BPH has been drawn up as an alternative to conventional treatments assuming possible lower side effects (Migdady et al., 1998; Zlotta et al., 2005; Keehn et al., 2016; Al-Trad et al., 2017). For instance, Al Trad et al ., (2017) demonstrated a positive impact of thymoquinone derived from $N$. Sativa on animal models in which they reported a reduction in prostate

\footnotetext{
${ }^{1}$ Department of Basic Medical Sciences, Faculty of Medicine, Yarmouk University, Irbid-21163, Jordan. ${ }^{2}$ Department of Biological Sciences, Faculty of Science, Yarmouk University, Irbid-21163, Jordan. ${ }^{3}$ Department of Biology, Jerash University, Jerash, Jordan. ${ }^{4}$ Department of Chemistry, Faculty of Science, Yarmouk University, Irbid-21163, Jordan. ${ }^{5}$ School of Pharmacy and Pharmaceutical Sciences, Ulster University, Coleraine BT521SA,UK. ${ }^{6}$ Vital Care Medical Center, Men's Health Center Limerick, Irelandv. ${ }^{7}$ Department of Pharmacy, Independent University, Dhaka-1229, Bangladesh. ${ }^{8}$ Department of Pharmacy and Pharmaceutical Sciences, Huddersfield University, UK. *For Correspondence: Bakshi-h@ulster.ac.uk. Mazhar Salim Al Zoubi and Wesam Al Khateeb have equal contribution in this study.
} 
size, epithelial hyperplasia, IL-6, TGF- $\beta 1$, and VEGF-A. In addition, the new nanotechnological approaches have been investigated as options for the treatment of BPH (Al Zoubi et al., 2019).

Moringa peregrina (Moringaceae) is classified as a rare medicinal plant in Jordan (Oran, 2014). It is a drought-tolerant tree, growing in different geographical locations from Dead Sea-Jordan along the Red Sea to Somalia, Arabian Peninsula, Persian Gulf, and Sinai Mountains (Osman and Abohassan, 2012). Various studies have investigated the chemical components and medicinal use of $M$. peregrina aerial parts and seeds. For instance, $M$. peregrina leaf extracts display antioxidant activities (Dehshahri et al., 2012) and proteins with antimicrobial activity (Somali et al., 1984; Lalas et al., 2012). Similarly, the extracts of different moringa species are reported to possess effective antitrypanosomally, cardioprotective, hepatoprotective, antihypertensive, diuretic, and anti-diabetic activities (Morton, 1991; Gilani et al., 1994; Pal et al., 1995; Faizi et al., 1998; Ghasi et al., 2000; Pari and Kumar, 2002; Ayyari et al., 2014). Furthermore, toxicological studies on $M$. peregrina extracts showed a safe and non-toxic effect on the liver by measuring different biochemical parameters and histology (El-Hak et al., 2018). Studies on anticancer effects of M. oleifera extract in different models including breast, leukemias, hepatocarcinoma and colorectal cancers showed no toxicity signs (Khalafalla et al., 2010; Nair and Varalakshmi, 2011; Jung, 2014; Al-Asmari et al., 2015; Elsayed et al., 2016). However, to the best of our knowledge, no study is reported on inflammation associated with testosterone-induced prostate hyperplasia and its effect on biochemical parameters. Therefore, in the current study, we aimed to investigate the anti-inflammatory and biochemical effects of $M$. peregrina leaf extracts on testosterone-induced benign prostatic hyperplasia in rats.

\section{Materials and Methods}

The aerial parts of the $M$. peregrina were collected by Prof. Wesam Al-Khateeb (Professor of Botany at the Department of Biological Sciences at the Faculty of Sciences at Yarmouk University) during the spring of 2019 from the Dead Sea area/Jordan $\left(31^{\circ} 35^{\prime} 52.6^{\prime \prime} \mathrm{N}\right.$ 35'33'39.3"E, 31.597931, 35.560911) and formally identified by Prof. Ahmad El Oqlah (Professor of Taxonomy at the Department of Biological Sciences at the Faculty of Sciences at Yarmouk University).

\section{Ethanolic Extract (EE)}

Aerial parts of the $M$. peregrina including leaves were dried in shade at room temperature $\left(24\right.$ to $\left.26^{\circ} \mathrm{C}\right)$. This was grounded into a powder and stored in a closed flask. Ethanolic extraction was performed on $50 \mathrm{~g}$ of $M$. peregrina powder by mixing with $500 \mathrm{~mL}$ of $95 \%$ ethanol followed by shaking (120 rpm/30 min) a precipitate was formed at 72 hours. The extract was filtered by Whatman filter paper then concentrated using a rotary evaporator and air-dried (Al-Qudah, Onizat et al. 2021).

\section{Oil Extract (OE)}

Essential oil separation was performed by the hydrodistillation approach using a Clevenger-type apparatus. Briefly, $100 \mathrm{~g}$ of $M$. peregrina plant fresh leaves were distilled for 3 hours in $200 \mathrm{ml}$ water. The recovered essential oil was dried over anhydrous sodium sulfate and stored at $4^{\circ} \mathrm{C}$ until use (Lakshmi and Nandagopal, 2017).

\section{Aqueous Extract (AE)}

For the aqueous extraction, $10 \mathrm{~g}$ of air-dried aerial parts of $M$. peregrina specimens were mixed with warm distilled water $\left(\sim 65^{\circ} \mathrm{C}\right)$, followed by filtration and evaporation to prepare a dried product (Koheil et al., 2011).

\section{Oral Acute Toxic Study}

All animal procedures and protocols were approved by the research and ethics committee at Yarmouk University under the following approval number: REC/YU/2686/107. Male Sprague-Dawley rats (weighing 220-250 g; $n=5 /$ group) were prepared by the animal house unit at Yarmouk University. Different doses of oil, aqueous and ethanolic extracts of $M$. peregrina were used to estimate the mortality and any sign of toxicity for the first 24 hours, and the LD50 was checked daily for 14 days.

\section{Experimental Design}

The administration routes of different extracts of M. Peregrina were as the following: Oil extract (OE): 50, $100, \mathrm{mg} / \mathrm{kg}$ (subcutaneous), EE: $500 \mathrm{mg} / \mathrm{kg}$ (orally), and (Aqueous extract) AE: $1000 \mathrm{mg} / \mathrm{kg}$ (orally). Experimental rats were randomly assigned to 6 groups. G1: normal control (100 $\mu \mathrm{L}$ corn oil subcutaneously), G2: BPH group which received testosterone propionate $(3 \mathrm{mg} /$ $\mathrm{kg} /$ subcutaneously, diluted in corn oil in a volume of $100 \mu \mathrm{l}$ ) for benign prostatic hyperplasia, induction. $\mathrm{G} 3$ : testosterone propionate induced $\mathrm{BPH}+\mathrm{OE}$ of M. peregrina (50 mg/kg/subcutaneously), G4: testosterone propionate induced $\mathrm{BPH}+\mathrm{OE}$ of $M$. peregrina $(50 \mathrm{mg} /$ $\mathrm{kg}$, subcutaneously), G4: testosterone propionate induced $\mathrm{BPH}+\mathrm{OE}$ of $M$. peregrina $(100 \mathrm{mg} / \mathrm{kg}$, subcutaneously), G5: testosterone propionate induced $\mathrm{BPH}+\mathrm{EE}$ of $M$. peregrina $(500 \mathrm{mg} / \mathrm{kg}$, orally) and G6: testosterone-induced $\mathrm{BPH}+\mathrm{AE}$ of $M$. peregrina $(1,000$ $\mathrm{mg} / \mathrm{kg}$, orally).

After 3 weeks of treatment, all animals were sacrificed under anesthetic conditions and their prostatic tissue specimens were immediately resected for histological and molecular procedures. Part of the tissue specimens was stored in liquid nitrogen for RNA isolation while other parts were washed with normal saline and processed for the preparation of histological slides as previously described (Al-Trad et al., 2017; Al Zoubi et al., 2019). Briefly, Spin Tissue Processor STP-120 (Thermo Fisher Scientific, USA) was used for fixation, clearing and dehydration. Finally, paraffin blocks were stored at room temperature until use.

\section{Prostate Weight Index and Histology}

The prostate-weight to body weight (PW/BW) ratios of the experimental rats were calculated $(\mathrm{mg} / \mathrm{g})$. For histological slide preparation, serial sections of 
$5 \mu \mathrm{m}$ thickness were obtained using Leica RM 2135 microtome (Leica Biosystem, Germany). Sections were deparaffinized, rehydrated and stained with Mayers Haematoxylin and counterstained with Eosin as previously described (Al-Trad et al., 2017; Al Zoubi et al., 2019). Glass coverslips were added using Canada Balsam. The prepared slides were visualized under a light microscope B-150 DB (Optika, Italy) to measure the prostate epithelial thickness using Image $\mathrm{J}$ software (NIH, Bethesda, MD, USA).

\section{RNA preparation and Reverse Transcription}

RNA extraction was performed using an RNA isolation kit according to the manufacturer's instructions (JenaBioscience, Germany). The extracted RNA quantity and integrity were determined using the QuantiFluor RNA System (Promega, Madison, USA) and Quantus Fluorometer (Promega, Madison, USA). cDNA was prepared using a commercially available kit according to the manufacturer's instructions (RevertAid First Strand cDNA Synthesis Kit, Thermo Scientific, Lithuania) and stored at $-20^{\circ} \mathrm{C}$ until RT-PCR procedure.

\section{Quantitative Real-Time PCR ( $q R T-P C R$ )}

The levels of IL-6, VEGF and PCNA were assessed by RT-PCR using specific pairs of primers (Table 1). The thermal cycler amplification was carried out on Line-Gene 9600 Real-Time PCR system (Bioer Technology, Bingjiang, China). Beta-actin ( $\beta$-actin) gene was used as a reference gene for the evaluation of the aforementioned gene expressions. The RT-PCR reaction was performed using SYBR-PCR master-mix (lunaRUnversal qPCR Master Mix) according to the recommended procedure. The relative gene expression levels were determined by the $2^{-\Delta \Delta \mathrm{CT}}$ method as described by Livak and Schmittgen (Livak and Schmittgen 2001). Finally, levels of gene expression were expressed as a normalized ratio of gene expression relative to $\beta$-actin mRNA level.
Determination of liver function, renal function, lipid profile and Glucose

Alanine transaminase (ALT) and aspartate transaminase (AST) enzyme activity were measured using ALT/GPT BR kit (Montgat Barcelona, Spain) according to the manufacturer's instructions. Albumin was measured using (BCG, Bromocresol Green) albumin assay kit (ACROMEX). Similarly, Creatinine was measured using the enzymatic creatinine method (BIOLABO REAGENT, Maizy, France) and urea was analyzed using the UREA/ BUN - COLOR (Biosystems S.A. Costa Brava 30, Barcelona, Spain). Lipid profile parameters such as Cholesterol level were measured using the cholesterol LR (ACROMEX) and Triglycerides level was measured using TRIGLYCERIDES MR (LiNEAR CHEMICALS, SL) kit according to the manufacturer's instructions. The glucose level was measured using the glucose (TRINDER) GOD/ PAP(Glucose Oxidase/Peroxidase) method (ACROMEX) kit according to the manufacturer's instructions.

\section{Statistical analysis}

GraphPad Prism 6 (GraphPad, San Diego, CA, USA) software was used for the analysis of all data and expressed as mean \pm SEM. Analysis of variance (ANOVA) was calculated to compare between different groups. $\mathrm{P} \leq 0.05$ was considered statistically significant.

\section{Results}

\section{Histological examinations}

The histological examination of the normal prostate gland from the control group, showed normal features of the prostate gland, mainly in the gland sizes, stroma, epithelial thickness, and folding. On the other hand, testosterone induced $\mathrm{BPH}$ rats exhibited prostatic epithelial hyperplasia with a noticeable enlargement in the prostate size and a significant increase in gland sizes, stroma and epithelial cells (Figure 1). Compared to the

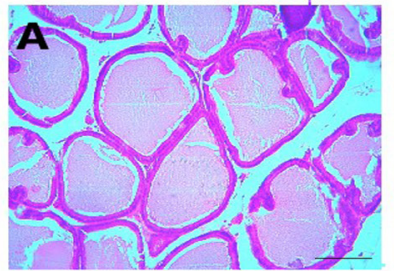

Control

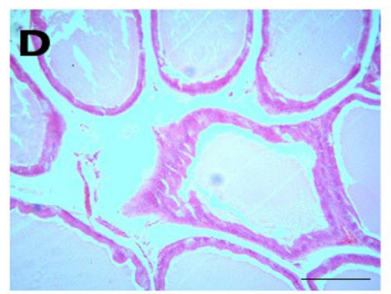

$\mathrm{BPH}+100$ Oil

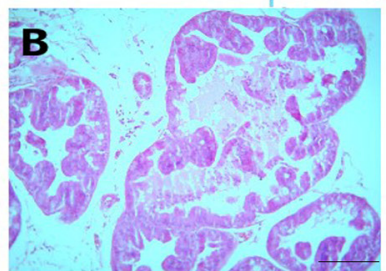

Testosterone $(\mathrm{BPH})$

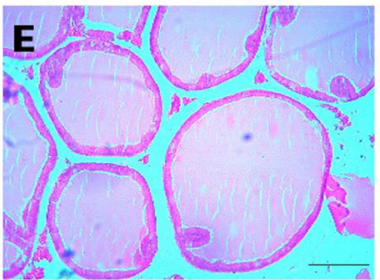

$\mathrm{BPH}+500$ Ethanol

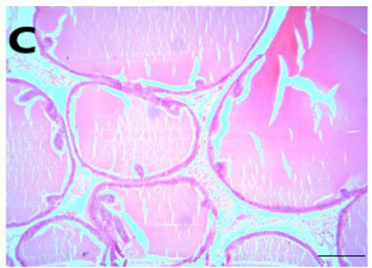

$\mathrm{BPH}+50$ Oil

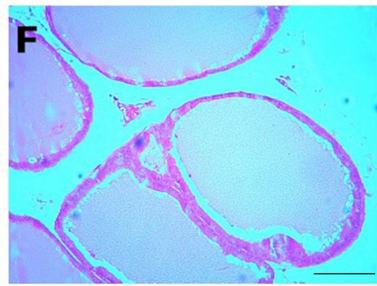

$\mathrm{BPH}+1000 \mathrm{Aq}$

Figure 1. Histological Features of the Prostatic Tissues (epithelial thickness), A, Control: Normal prostate gland. B, BPH (Testosterone): Testosterone-induced BPH.C, 50 Oil: Testosterone-induced BPH treated with $50 \mathrm{mg} / \mathrm{kg}$ of oil extract. D, 100 Oil: Testosterone-induced BPH treated with $100 \mathrm{mg} / \mathrm{kg}$ of oil extract. E, 500 ethanol: Testosteroneinduced BPH treated with $500 \mathrm{mg} / \mathrm{kg}$ of ethanol extract. F, 1000 aqueous: Testosterone-induced BPH treated with $1000 \mathrm{mg} / \mathrm{kg}$ of aqueous extract. Magnification of $200 \mathrm{X}$ and Scale bar at $50 \mu \mathrm{m}$. 

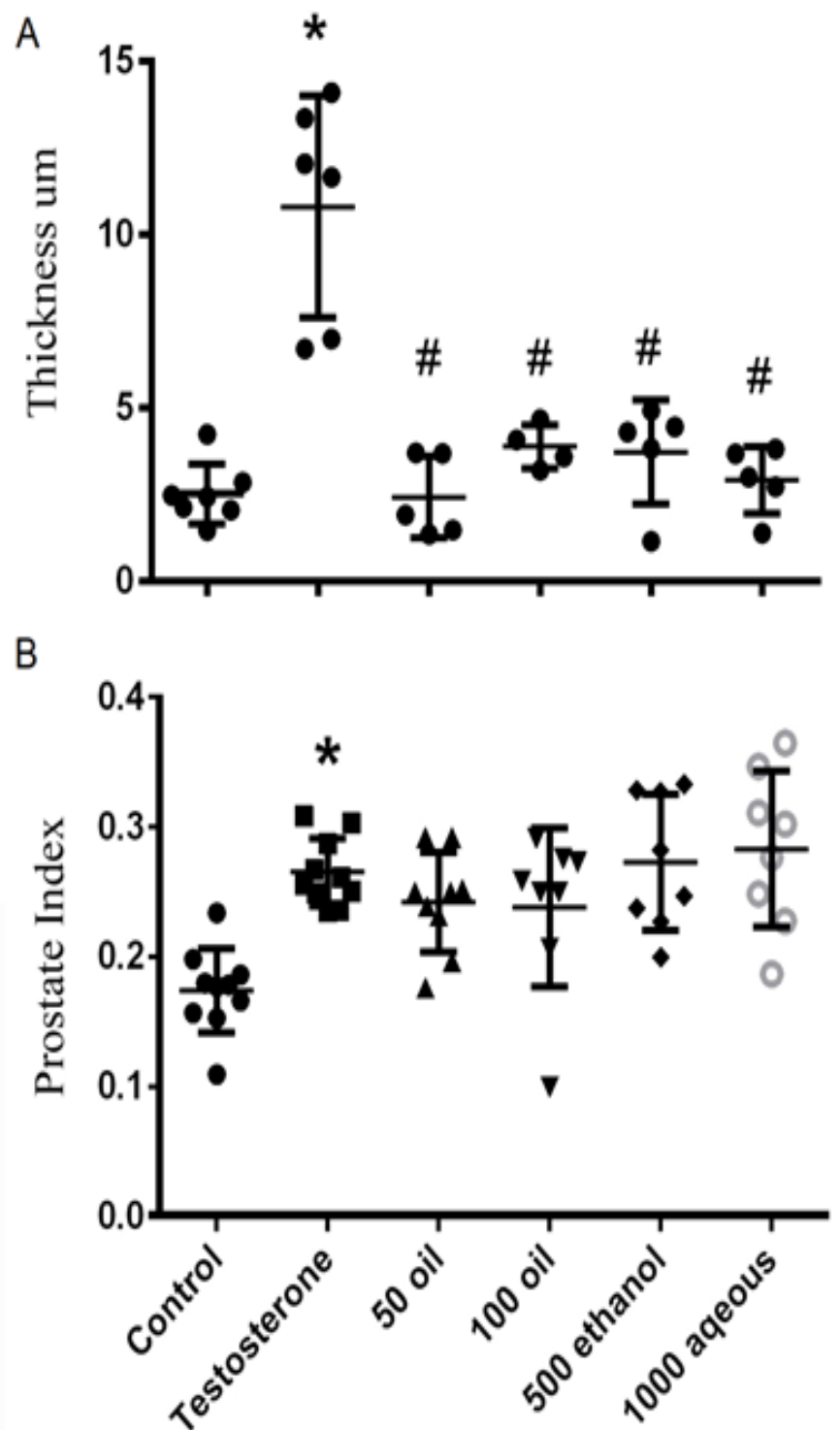

Figure 2. A. Epithelial thickness and B. Prostate index (PW/BW ratio). Control: Normal prostate gland. Testosterone: Testosterone-induced BPH. 50 Oil: Testosterone-induced BPH treated with $50 \mathrm{mg} / \mathrm{kg}$ of oil extract. 100 Oil: Testosterone-induced BPH treated with $100 \mathrm{mg} / \mathrm{kg}$ of oil extract. 500 ethanol: Testosterone-induced BPH treated with $500 \mathrm{mg} / \mathrm{kg}$ of ethanol extract. 1000 aqueous: Testosterone-induced BPH treated with $1000 \mathrm{mg} / \mathrm{kg}$ of aqueous extract.

untreated testosterone-induced BPH $(\mathrm{G} 2)$, the treated groups of testosterone-induced BPH showed significant improvement in the histological feature of prostate glands $(\mathrm{P}<0.05)$ (Figures 1 and 2).

\section{Prostate weight to body weight ratio ( $P W: B W)$}

As expected, PW: BW ratio of the testosteroneinduced BPH (G2) group displayed a substantial increase compared to the control group. On the other hand, testosterone-induced $\mathrm{BPH}$ rats that were treated with $M$. peregrina extracts (oil, ethanol and aqueous) did not show any significant reduction in the PW: BW ratios (Figure 1).

\section{Prostate epithelial thickness}

Testosterone-induced $\mathrm{BPH}$ groups treated with various M. peregrina extracts such as 50 and $100 \mathrm{mg} / \mathrm{kg} \mathrm{OE}$ (oil extract), $500 \mathrm{mg} / \mathrm{kg} \mathrm{EE}$ (ethanolic extract) and $1000 \mathrm{mg} /$ $\mathrm{kg} \mathrm{AE}$ (aqueous extract) showed improved features of their prostate glands such as in epithelial thickness and stromal folding. The $\mathrm{OE}$ and $\mathrm{AE}$ extracts of $M$. peregrina showed a significant reduction in epithelial thickness in the treated groups compared to the BPH-untreated group as presented in Figures 2Aand 2B.

\section{Quantitative real time-PCR ( $q R T-P C R)$}

\section{IL-6 expression}

The prostatic level of mRNA was significantly increased in the BPH group (G2) compared to the control group. However, a significant reduction in the expression of the IL- 6 gene was observed in treated groups compared to the $\mathrm{BPH}$ group $(\mathrm{P}<0.05)$ (Figure $3 \mathrm{~A})$. 
A
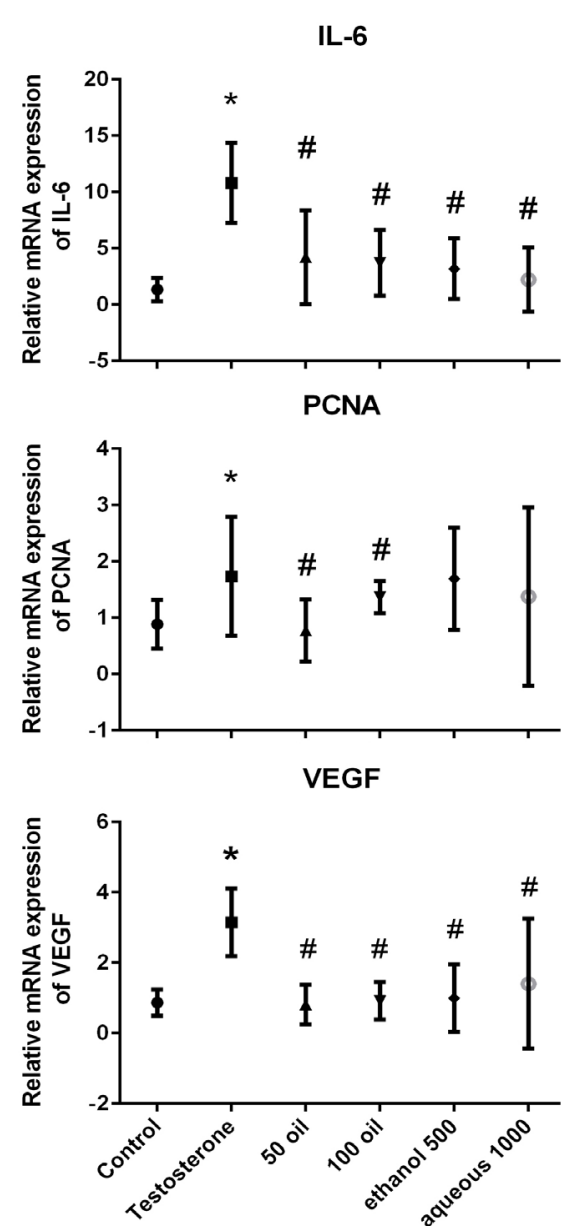

B
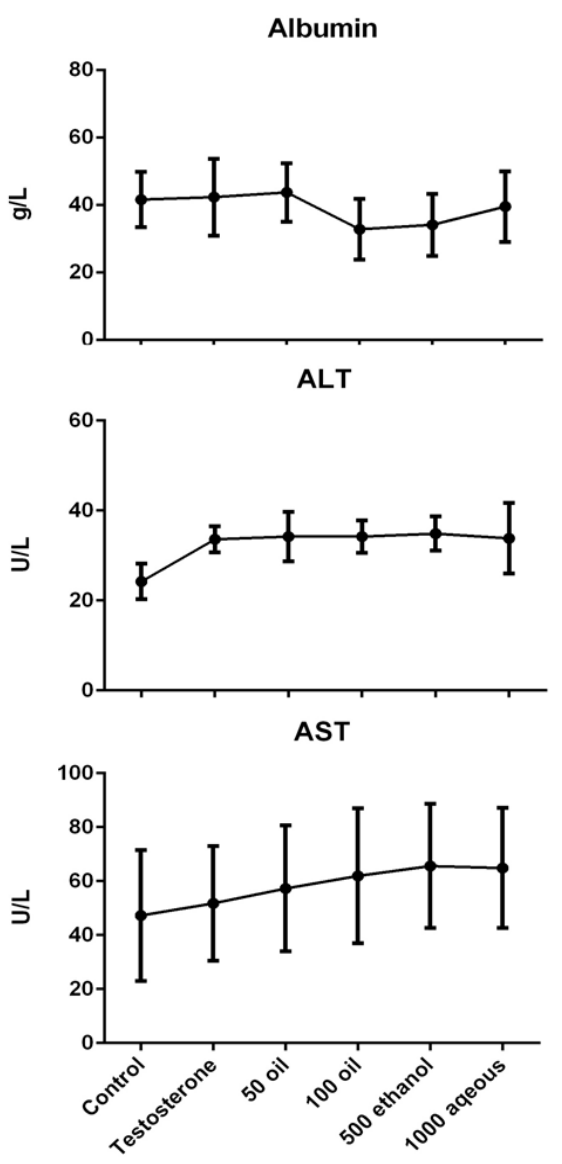

Figure 3. A). IL-6, PCNA and VEGF-A mRNA relative expression. Control: Normal prostate gland. Testosterone: Testosterone-induced BPH. 50 Oil: Testosterone-induced BPH treated with $50 \mathrm{mg} / \mathrm{kg}$ of oil extract. 100 Oil: Testosterone-induced BPH treated with $100 \mathrm{mg} / \mathrm{kg}$ of oil extract. 500 ethanol: Testosterone-induced BPH treated with $500 \mathrm{mg} / \mathrm{kg}$ of ethanol extract. 1000 aqueous: Testosterone-induced BPH treated with $1000 \mathrm{mg} / \mathrm{kg}$ of aqueous extract. B). Liver function test, Albumin, ALT and AST activity. Control: Normal prostate gland. Testosterone: Testosteroneinduced BPH. 50 Oil: Testosterone-induced BPH treated with $50 \mathrm{mg} / \mathrm{kg}$ of oil extract. 100 Oil: Testosterone-induced $\mathrm{BPH}$ treated with $100 \mathrm{mg} / \mathrm{kg}$ of oil extract. 500 ethanol: Testosterone-induced BPH treated with $500 \mathrm{mg} / \mathrm{kg}$ of ethanol extract. 100 aqueous: Testosterone-induced BPH treated with $1000 \mathrm{mg} / \mathrm{kg}$ of aqueous extract.

\section{PCNA expression}

The testosterone induced BPH group (G2) displayed a significant increase in the mRNA expression level of the PCNA gene compared to the normal control group. On the other hand, a significant decline in expression of levels of the PCNA gene was noticed in the testosteroneinduced $\mathrm{BPH}+\mathrm{OE}$ treated group $(50$ and $100 \mathrm{mg} / \mathrm{kg}$ ) $(\mathrm{P}<0.05)$ compared to the testosterone-induced $\mathrm{BPH}$ untreated group (Figure 3A).

\section{$V E G F-A$ expression}

Not surprisingly, the testosterone-induced BPH group (G2) significantly overexpressed the prostatic mRNA level of the VEGF-A gene compared to the control group. However, a significant reduction in expression of the VEGF-A gene was observed in $\mathrm{BPH}+\mathrm{OE}, \mathrm{BPH}+\mathrm{EE}$ and $\mathrm{BPH}+\mathrm{AE}$ treated groups compared to the $\mathrm{BPH}$ group $(\mathrm{P}<0.05)$ (Figure $3 \mathrm{~A})$.

\section{Biochemical parameters}

Measurement of ALT and AST enzyme activities and the concentration of albumin did not show any significant difference between all animal groups which implies the lack of toxicity of $M$. peregrina leaf extracts as shown in figure $3 \mathrm{~B}$. In addition, renal function tests (urea and creatinine) showed a lack of toxicological effect of $M$. peregrina leaf extracts as shown in Figure 4A. The other biochemical parameters (glucose, triglycerides and cholesterol) showed no difference between all experimental groups as shown in Figure 4B.

\section{Discussion}

This study investigated the effect of administering leaf extracts of M. peregrina on testosterone-induced $\mathrm{BPH}$ in vivo using male Sprague-Dawley rats. BPH is associated with both stromal growth and epithelial growth due to active stromal cell proliferation and reduced glandular apoptosis, respectively (Kyprianou et al., 1998; Lee and Peehl, 2004; Zhang et al., 2006). Our results demonstrated an improvement in the histological morphology of 
A
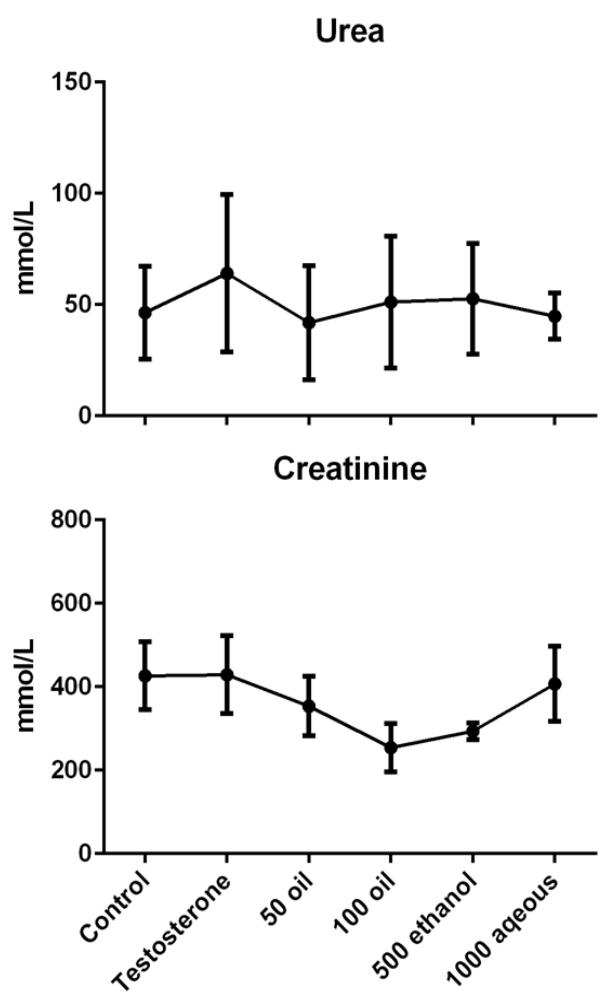

B

TG
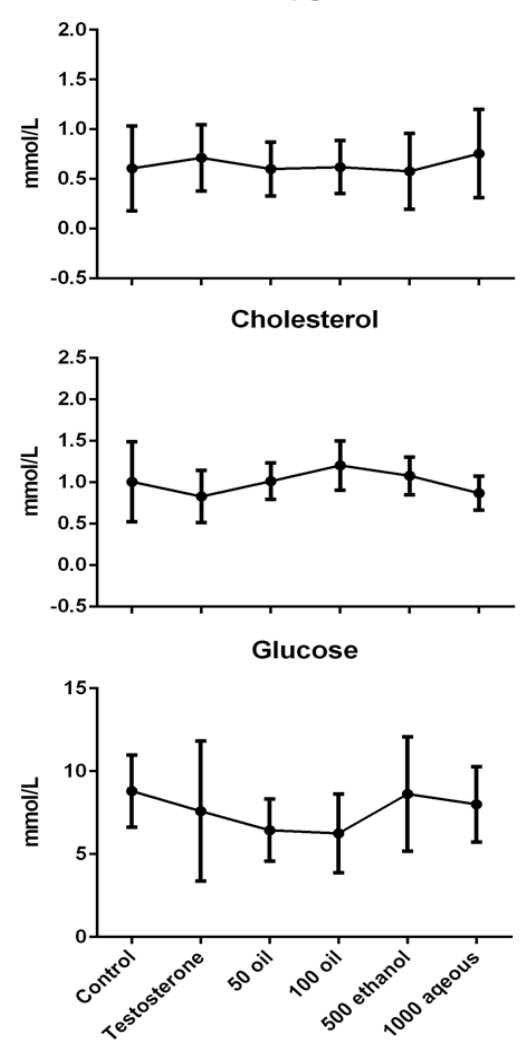

Figure 4. A, Renal function test by urea and creatinine. Control: Normal prostate gland. Testosterone: Testosteroneinduced BPH. 50 Oil: Testosterone-induced BPH treated with $50 \mathrm{mg} / \mathrm{kg}$ of oil extract. 100 Oil: Testosterone-induced BPH treated with $100 \mathrm{mg} / \mathrm{kg}$ of oil extract. 500 ethanol: Testosterone-induced BPH treated with $500 \mathrm{mg} / \mathrm{kg}$ of ethanol extract. 1000 aqueous: Testosterone-induced $\mathrm{BPH}$ treated with $1000 \mathrm{mg} / \mathrm{kg}$ of aqueous extract; B. Triglyceride, cholesterol and glucose concentration. Control: Normal prostate gland. Testosterone: Testosterone-induced BPH. 50 Oil: Testosterone-induced BPH treated with $50 \mathrm{mg} / \mathrm{kg}$ of oil extract. 100 Oil: Testosterone-induced BPH treated with $100 \mathrm{mg} / \mathrm{kg}$ of oil extract. 500 ethanol: Testosterone-induced BPH treated with $500 \mathrm{mg} / \mathrm{kg}$ of ethanol extract. 1000 aqueous: Testosterone-induced BPH treated with $1000 \mathrm{mg} / \mathrm{kg}$ of aqueous extract.

testosterone induced BPH after treatment with oil, ethanol and aqueous extracts of $M$. peregrina leaves. In particular, the glandular epithelial thickness showed a significant reduction as well as a loss of stromal foldings in the treated BPH groups compared to the untreated animals. At the molecular level, we investigated the expression markers of BPH development such as VEGF-A, IL-6 and PCNA. The overexpression of these genes is linked to the pathogenesis of BPH (Soulitzis et al., 2006; Zhong et al., 2008; Nguyen et al., 2014). In the current study, we demonstrated a reduction in mRNA expression of VEGF-A, IL-6 and PCNA genes in the treated BPH groups compared to the untreated BPH group. These findings are consistent with the histological improvement features in the BPH tissues.

Testosterone induction of BPH in rats showed a dramatic change in the histological morphology of the prostatic glandular structure mainly the thickness of epithelial cells. Consistently, testosterone-induced $\mathrm{BPH}$ showed a significant increase in the $\mathrm{PW} / \mathrm{BW}$ ratio compared with the control group; nevertheless, treatment of BPH rats with $M$. peregrina leaf extracts did not show a significant enhancement in $\mathrm{PW} / \mathrm{BW}$ ratios. In a previous study, $M$. peregrine $\mathrm{OE}$ exhibited an anti-proliferation activity effect on MCF-7, HepG2 and HCT-116 cell lines which were attributed to the apoptotic effect of the fatty acid constitution (El Baky and El-Baroty, 2013). Despite the beneficial effect of all leaf extracts of $M$. peregrina (OE, EE, and AE), it was noticed that OE showed the most powerful amelioration of prostate histology in the treated BPH rats compared to the untreated BPH group. Our findings support the beneficial effects of the OE of $M$. peregrina in the treatment of BPH by improving the histological morphology of the epithelial cells but not the prostate size which may need prolonged treatment to elicit a possible effect on the prostate index. Also, the effect of the EE of M.peregrina leaves may be attributed to the high contents of polyphenols, specifically tannins and flavonoids which were found in similar species M. oleifera (Arya et al., 2014). It has been suggested that phenolic compounds exhibit anticancer, antioxidant, hepatoprotective, antimicrobial and anti-inflammatory effects (Al-Owaisi et al., 2014). Moreover, previous findings demonstrated the presence of anti-oxidant and anti-proliferative compounds in M. peregrina (Padayachee and Baijnath, 2012). Consistently, in the current study, the $\mathrm{OE}$ treatment of $M$. peregrina showed a significant reduction in gene expression of PCNA, the proliferative marker in prostatic hyperplasia which is demonstrated by the reduction of epithelial thickness.

In addition, BPH development relies on the angiogenesis 
process which is emphasized by the overexpression of the VEGF-A (Jackson et al., 1997; Soulitzis et al., 2006; Kim et al., 2011). Moreover, VEGF-A promotes the migration of endothelial cells (Urbich et al., 2005; Suzuki et al., 2008; Hayakawa et al., 2012). In the current study, a significant reduction in the expression of the VEGF-A gene was observed in the $\mathrm{BPH}+\mathrm{OE}, \mathrm{BPH}+\mathrm{EE}$ and $\mathrm{BPH}+\mathrm{AE}$ treated groups compared to the testosteroneinduced $\mathrm{BPH}$ control group $(\mathrm{P}<0.05)$.

This inflammation process is one of the major markers of the BPH condition. For instance, IL-2, IL-6 and TNF-alpha cytokines have been reported to be elevated in BPH patients (Michalaki, Syrigos et al. 2004, Penna, Mondaini et al. 2007, Bouraoui, Ricote et al. 2008). Accumulating evidence supports the role of inflammation in the induction of epithelial proliferation and abnormal stromal morphology (Al-Trad et al., 2017). Our findings showed a significant increase in the expression of IL-6 mRNA in the testosterone-induced BPH group. However, a significant reduction in the level of the IL- 6 gene was noticed in the BPH treated groups $(\mathrm{P}<0.05)$.

The toxicological effect of the $M$. peregrina leaf extracts on rats have been assessed by the analysis of liver and kidney biochemical markers. Alanine aminotransferase activity (ALT), aspartate aminotransferase activity (AST) and albumin were measured as general markers for liver function. These results did not show any significant difference between all tested groups. This indicates a safe use of $M$. peregrina leaf extracts in the animal model. However, the toxicological effect should be further investigated in larger-scale studies utilizing different animal models. Moreover, the renal function test which measures urea and creatinine assumed that $M$. peregrina leaf extracts have no toxicological effects on renal function. Furthermore, the glucose and lipid profile levels did not show any significant difference between all tested rats. Collectively, our results showed a nontoxic effect of M. peregrina leaf extracts on the rats.

In conclusion, the results of the current research suggest that $M$. peregrina leaf extracts (OE, EE and AE) are effective anti-inflammatory, anti-proliferative and anti-angiogenic medicinal treatment in vivo. In particular, OE showed the most powerful anti-inflammatory, anti-proliferative and anti-angiogenic effect against the development of BPH. Importantly, $M$. peregrina leaf extract showed no signs of toxicity in liver and kidney function tests. The outcomes of this study support the use of medicinal plants as an alternative option for the available treatments of BPH which have been associated with undesirable side effects (Traish et al., 2011). However, before coming to a conclusive remark more research is needed to fully understand the role of M. peregrina in testosterone-induced BHP.

\section{Author Contribution Statement}

Study conception and design; Hamid Bakshi, Murtaza Tambuwala and Mazhar Alzoubi.; data collection: Wesam Al Khateeb, Musab El-Oqlah, Mu'ath Migdady, Manal Essam, Muna Bozoor; analysis and interpretation of results Ahmad El-Oqlah, Samah Almubarak, MahmoudAlQudah,
KhalidAlBatayneh; draft manuscript preparation: Michella Mekhela, Ahmed Elokda, PrawejAnsari JMA Hannan, Mohamed M Nasef. All authors reviewed the results and approved the final version of the manuscript.

\section{Acknowledgments}

We are very thankful to the Deanship of Scientific Research and Graduate Studies at Yarmouk University for the financial support to complete this project. And Special thanks to Dr. Bahaa Al-Trad for his generous support in his laboratory. And we thank Mr. Adel Rababah for his help in the production of our figures.

\section{Conflict of interest}

We are all authors declare there is no conflict of interest in this work.

\section{References}

Al-Asmari AK, Albalawi SM, Athar MT, et al (2015). Moringa Oleifera as an anti-cancer agent against breast and Colorectal cancer cell lines. PLoS One, 10.

Al-Owaisi M, Al-Hadiwi N, Khan SA (2014). Gc-Ms analysis, determination of total phenolics, flavonoid content and free radical scavenging activities of various crude extracts of Moringa Peregrina (Forssk.) Fiori Leaves. Asian Pac J Trop Biomed, 4, 964-70.

Al-Qudah MA, Onizat MA, Alshamari AK, et al (2021). Chemical composition and antioxidant activity of Jordanian Artemisia Judaica L. as affected by different drying methods. Int J Food Properties, 24, 482-92.

Al-Trad B, Al-Zoubi M, Qar J, et al (2017). Inhibitory effect of thymoquinone on testosterone-induced benign prostatic hyperplasia in Wistar Rats. Phytotherapy Res, 31, 1910-5.

Al Zoubi MS, Al-Batayneh KM, Al-Trad B, et al (2019). Evaluation Of Vitamin B12, Folate and Ferritin Serum levels in Jordanian population. J Nutr Sci and Vitaminol, 65, 309-17.

Arya V, Kumar D, Gautam M (2014). Phytopharmacological review on flowers: Source Of Inspiration For Drug Discovery. Biomed Prev Nutr, 4, 45-51.

Ayyari M, Salehi P, Ebrahimi SN, et al (2014). Antitrypanosomal isothiocyanate and thiocarbamate glycosides from Moringa Peregrina. Planta Med, 80, 86-9.

Bouraoui Y, Ricote M, García-Tuñón I, et al (2008). Proinflammatory cytokines and prostate-specific antigen in hyperplasia and human prostate cancer. Cancer Detect Prev, 32, 23-32.

Buford K, Polland A, Khurgin J, et al (2019). Pd19-02 contemporary active clinical trials in Benign prostatic hyperplasia. J Urol, 201, E372-E372.

Clifford G, Farmer R (2000). Medical therapy for Benign prostatic hyperplasia: A Review Of The Literature. Eur Urol, 38, 2-19.

Dehshahri S, Wink M, Afsharypuor S, Asghari G, Mohagheghzadeh A (2012). Antioxidant activity of methanolic leaf extract of Moringa Peregrina (Forssk.) Fiori. Res In Pharm Sci, 7, 111.

El-Hak HNG, Moustafa ARA, Mansour SR (2018). Toxic effect of Moringa Peregrina seeds on histological and biochemical analyses of adult male Albino Rats. Toxicol Rep, 5, 38-45.

El Baky HA, El-Baroty GS (2013). Characterization Of Egyptian Moringa Peregrine Seed Oil And Its Bioactivities. Int $J$ Manage Sci Bus Res, 2, 98-108.

Asian Pacific Journal of Cancer Prevention, Vol 23 
Elsayed EA, Sharaf-Eldin MA, El-Enshasy HA, Wadaan M (2016). In vitro assessment of anticancer properties of Moringa Peregrina essential seed oil on different cell lines. Pakistan J Zool, 48.

Faizi S, Siddiqui BS, Saleem R, Aftab K, Shaheen F (1998). Hypotensive Constituents From The Pods Of Moringa Oleifera. Planta Med, 64, 225-8.

Fourcade RO, Théret N, Taïeb C, Group BUS (2008). Profile And Management Of Patients Treated For The First Time For Lower Urinary Tract Symptoms/Benign Prostatic Hyperplasia In Four European Countries. Bju Int, 101, 1111-8.

Ghasi S, Nwobodo E, Ofili J (2000). Hypocholesterolemic effects of crude extract of leaf of Moringa Oleifera lam in high-fat diet fed wistar rats. $J$ Ethnopharmacol, 69, 21-25.

Gilani AH, Aftab K, Suria A, et al (1994). Pharmacological studies on hypotensive and spasmolytic activities of pure compounds from Moringa Oleifera. Phytotherapy Res, 8 , 87-91.

Hayakawa K, Seo JH, Pham LDD, et al (2012). Cerebral endothelial derived vascular endothelial growth factor promotes the migration but not the proliferation of oligodendrocyte precursor cells in vitro. Neuroscience Lett, 513, 42-46.

Jackson MW, Bentel JM, Tilley WD (1997). Vascular endothelial growth factor (Vegf) expression in prostate cancer and benign prostatic hyperplasia. J Urol, 157, 2323-8.

Jung, IL (2014). Soluble extract from Moringa Oleifera leaves with a new anticancer activity. PLoS One, 9.

Keehn A, Taylor J, Lowe FC (2016). Phytotherapy for benign prostatic hyperplasia. Curr Urol Rep, 17, 53.

Khalafalla MM, Abdellatef E, Dafalla HM,et al (2010). Active principle from Moringa Oleifera lam leaves effective against two leukemias and a hepatocarcinoma. Afr J Biotechnol, 9, 846771.

Kim BH, Kim CI, Chang HS, et al (2011). Cyclooxygenase-2 overexpression in chronic inflammation associated with benign prostatic hyperplasia: Is It Related To Apoptosis And Angiogenesis Of Prostate Cancer?. Korean J Urol, 52, 253-9.

Koheil MA, Hussein MA, Othman SM, El-Haddad A (2011). Anti-Inflammatory and antioxidant activities of Moringa Peregrina seeds. Free Radicals Antioxidants, 1, 49-61.

Kyprianou N, Litvak JP, Borkowski A, et al (1998). Induction of prostate apoptosis by Doxazosin In Benign Prostatic Hyperplasia. J Urol, 159, 1810-5.

Lakshmi M, Nandagopal S (2017). Antimicrobial efficacy and phytochemical constituents of eessential oil on Coleus Zeylanicus (Benth.) Lh Cramer A Valuable Medicinal Plant. Der Pharm Lett, 9, 29-39.

Lalas S, Gortzi O, Athanasiadis V, Tsaknis J, Chinou I (2012). Determination of antimicrobial activity and resistance to oxidation of Moringa Peregrina seed oil. Molecules, 17, 2330-4.

Lee KL, Peehl DM (2004). Molecular and cellular pathogenesis Of benign prostatic hyperplasia. $J$ Urol, 172, 1784-91.

Livak KJ, Schmittgen TD (2001). Analysis of relative gene expression data using real-time quantitative Pcr and the $2^{-\Delta \delta c t}$ method. Methods, 25, 402-8.

Lowe FC, Dreikorn K, Borkowski A, et al (1998). Review of recent placebo-controlled trials utilizing phytotherapeutic agents for treatment of Bph. Prostate, 37, 187-93.

Mcvary KT (2006). Bph: Epidemiology And Comorbidities. The Am J Managed Care, 12, S122-8.

Michalaki V, Syrigos K, Charles P, Waxman J (2004). Serum Levels of Il-6 and Tnf-A correlate with clinicopathological features and patient survival in patients with prostate cancer. Br J Cancer, 90, 2312-6.
Migdady MAM (1998) . Effects Of Extract And Essential Oil Of Artemisia Judaica L. On The Testosterone Induced Benign Prostatic Hyperplasia In Rats. Yarmouk University.

Mirone V, Sessa A, Giuliano F, et al (2011). Current benign prostatic hyperplasia treatment: Impact On Sexual Function And Management Of Related Sexual Adverse Events. Int $J$ Clin Pract, 65, 1005-13.

Morton JF (1991). The Horseradish Tree, Moringa Pterygosperma (Moringaceae)-A Boon To Arid Lands?. Economic Botany, 45, 318-33.

Nair S, Varalakshmi K (2011). Anticancer, cytotoxic potential of Moringa Oleifera extracts on Hela cell line. J Nat Pharm, 2, 138-42.

Nguyen DP, Li J, Tewari AK (2014). Inflammation And Prostate Cancer: The Role Of Interleukin 6 (Il-6). Bju Int, 113, 986-92.

Oran SA (2014). The status of medicinal plants in Jordan. J Agricul Sci Technol, A, 4.

Osman HE, Abohassan AA (2012). Morphological and analytical characterization Of Moringa Peregrina populations in western Saudi Arabia. Int J Theor Appl Sci, 4, 174-84.

Padayachee B, Baijnath H (2012). An overview of the medicinal importance of Moringaceae. J Med Plants Res, 6, 5831-9.

Pal SK, Mukherjee PK, Saha B (1995). Studies on the antiulcer activity of Moringa Oleifera Leaf extract on gastric ulcer models in rats. Phytotherapy Res, 9, 463-5.

Pari L, Kumar NA (2002). Hepatoprotective activity of Moringa Oleifera on antitubercular drug-induced liver damage in rats. J Med Food, 5, 171-7.

Penna G, Mondaini N, Amuchastegui S, et al (2007). Seminal plasma cytokines and chemokines in prostate inflammation: Interleukin 8 As A Predictive Biomarker In Chronic Prostatitis/Chronic Pelvic Pain Syndrome And Benign Prostatic Hyperplasia. Eur Urol, 51, 524-33.

Smith T, Lynch M, Johnson J, Kawa K, Bauman H, Blumenthal M (2015). Herbal dietary supplement sales in us increase $6.8 \%$ in 2014. Herbalgram, 107, 52-9.

Somali M, Bajneid M, Al-Fhaimani S (1984). Chemical composition and characteristics Ofmoringa Peregrina seeds and seeds oil. J Am Oil Chemists'Soc, 61, 85-6.

Soulitzis N, Karyotis I, Delakas D, Spandidos DA (2006). Expression analysis of peptide growth factors Vegf, Fgf2, Tgfb1, Egf And Igf1 in prostate cancer and benign prostatic hyperplasia. Int J Oncol, 29, 305-14.

Suzuki Y, Montagne K, Nishihara A, Watabe T, Miyazono $\mathrm{K}$ (2008). Bmps promote proliferation and migration of endothelial cells via stimulation of Vegf-A/Vegfr2 and angiopoietin-1/Tie2 signalling. J Biochem, 143, 199-206.

Traish AM, Hassani J, Guay AT, Zitzmann M, Hansen ML (2011). Adverse side effects of $5 \alpha$-reductase inhibitors therapy: Persistent Diminished Libido And Erectile Dysfunction And Depression In A Subset Of Patients. J Sex Med, 8, 872-84.

Urbich C, Aicher A, Heeschen C, et al (2005). Soluble factors released by endothelial progenitor cells promote migration of endothelial cells and cardiac resident progenitor cells. J Mol Cell Cardiol, 39, 733-42.

Van Asseldonk B, Barkin J, Elterman DS (2015). Medical therapy for benign prostatic hyperplasia: A Review. Can $J$ Urol, 22, 7-17.

Zhang X, Zhang Q, Zhang Z, Na Y, Guo Y (2006). Apoptosis profiles in benign prostatic hyperplasia: Close Associations Of Cell Kinetics With Percent Area Density Of Histologic Composition. Urology, 68, 905-10.

Zhong W, Peng J, Wu D, et al (2008). Ki-67 And Pcna expression in prostate cancer and benign prostatic hyperplasia. Clin Invest Med, 2008, 8-15. 
Zlotta AR, Teillac P, Raynaud JP, Schulman CC (2005).

Evaluation of male sexual function in patients with lower urinary tract symptoms (Luts) associated with benign prostatic hyperplasia $(\mathrm{Bph})$ treated with a phytotherapeutic agent (Permixon $\left.{ }^{\circledR}\right)$, tamsulosin or finasteride. Eur Urol, 48, 269-76.

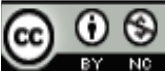

This work is licensed under a Creative Commons AttributionNon Commercial 4.0 International License. 